\title{
House Price Bubbles in China
}

\author{
Ting $\operatorname{Lan}^{1, *}$ \\ ${ }^{1}$ Department of Finance and Business Economics, University of Macau, Macau, China \\ *Correspondence: B1-A308, Block One, Faculty of Business Administration, University of \\ Macau, Av. Padre Tomas Pereira, Taipa, Macau, China. \\ Tel: 853-6322-7837.E-mail: Olivialan@umac.mo
}

Received: November 26, 2013 Accepted: December 17, 2013 Published: January 20, 2014

doi:10.5296/rae.v6i1.4946 URL: http://dx.doi.org/10.5296/rae.v6i1.4946

\begin{abstract}
This paper uses a vector of macroeconomic and monetary policy fundamental variables to investigate the existence of speculative bubbles on national residential house market in China over the period from Mar.1998 to Feb.2013.In the past few years, except the quantitative easing policy was implemented in USA, many monetary policy instruments also have been used on the asset markets in China, such as expansionary of monetary supply and lower benchmark interest rate and lending rate. These led to the hyperinflation happened in China and property price increased dramatically after 2009. Because of the booming in the real estate industry, we are interested in whether there is a housing bubble existing in the market. Three sets of bubble attributes are examined, including unit root test and co-integration procedures, we find no evidence of rational bubbles in the national housing market. The tests for duration dependence in the negative returns on house prices suggest that China housing market is not affected by rational bubbles. Overall, this essay proposes monetary policy and macroeconomic variables are important factors for the increasing of housing prices. It is also necessary for monetarists to consider about the impact of interest rates on housing prices.
\end{abstract}

Keywords: monetary policy; house prices; duration dependent test; speculative bubbles 


\section{Introduction}

In 1994, the former Chairman of the US Federal Reserve Board, Alan Greenspan talked about the central bank should pay more attention to asset price bubbles at the conference on celebrating the $300^{\text {th }}$ anniversary of the founding of Bank of England. Thus it raised the warm discussion on the relationship between asset prices and monetary policy around business cycles and central banks from the late 1990s. Real Estate is one of the most important assets which are owned by enterprises or residents. Because real estate has both consumption and investment characteristics, real estate price fluctuations or bubbles can deeply impact on real economy and financial system stability and also deeply impact other equity prices and financial assets. So the real estate prices fluctuations and bubbles burst raised serious challenge to monetary policy.

Recent years the lack of financial markets regulation and institution deregulation have caused the subprime mortgage market bubble in the United States and spread out internationally which led to the global financial market crisis in year of 2007 and undermine financial stability. Additionally, the European sovereign debt crisis happened in the late 2009. The number of countries such as Italy, Greece and Spain fell in much quickly in its GDP. The tax revenue declined, the government spending increased and real estate bubbles burst, which caused European countries economy fall into recession. The investors have to reconsider about the safety of their investment and relocated their assets away from risky sovereign debts and equities. Although the EU countries used emergency bailouts and try to rescue the economy and banking sectors, there is still no good sign for economy recovery. Furthermore, a large number of bankruptcies of financial institutions caused the capital shortage problems and imposed a negative shock on the real economy in the US and Japan. In order to repay the government debts and pull their economies out of recession, US government is forced to use loose monetary policy, reduce the rates and "print" more money. This option have further weaker the world economy and caused cross border inflation rising risk.

In the late 1970s, China government had implemented a complete welfare-housing system. The constructed welfare housing is under the government administrative control. The low lending and distributing houses to citizens are based on government annual housing plan. Therefore, there is no real estate market existed till year 1998. In July 1998, central government announced the notice on the deepening of housing reform and fastens housing construction policy. Which stipulated the welfare-housing distribution system was abolished; all cities implemented the policy of house monetization allocation and residents need to buy commercial apartments in the residential property trading market. This symbolized that real estate market began to function as an invisible hands to solve residence problems. After twenty years fast growing period, China's economy has been growing rapidly. Given its stable political environment, rapid increasing of growth domestic products, low production cost, large consumer market, greater potential in demand and improved monetary policy system by central government, China has led to a rise in the annual average disposal income of all residents. This has in turn led to an increase of consumption. And eventually benefits the China real estate market. 
Although the global financial crisis and subsequent downturn happened in autumn 2008 that brought temporary damage to the real estate market and stock market in China, central government announced a four trillion RMB (586 Billion US Dollars) stimulus package to encourage the economy on a stable increase on Nov. $9^{\text {th }} 2008$ and use loose monetary policy to encourage production and consumption. The capital injection was mainly spent on housing, rural infrastructure, water, electricity, transportation, the environment, technological innovation, tax cuts and the commercial banks' credit ceiling as well in 10 major areas during the last two years. The central government allows more lending to develop housing, roads and bridges. This has driven employment in areas of manufacturing, steel, cement and other sectors of the economy. Banks also accelerated the development of credit guarantee services, and one third of the total lending activities have been accounted as the home mortgage loans. The Bank of China cut the base lending rate and deposit-reserve rate four times from September $16^{\text {th }}$ to December $23^{\text {rd }}, 2008$. So within three months, one year base lending rate and deposit-reserve rate have been fallen 2.16 basis points and 4 basis points. Therefore, comparing with western developed countries suffering serious economy recession, the decrease in the base lending rate and deposit-reserve rate, the loosening of controls on mortgage loan for business and household and expansionary money supply have no doubt led China to face the increasing of ambitious GDP target and follows by the quickly recovery of real estate markets. At the same time, the excess liquidity caused high inflation and more money flows into real estate market.

There have other factors that may have led to rising housing prices. Another possible contributor includes the adoption of quantitative easing policy by the United States Federal Reserve Bank since early 2009. The Fed's two major quantitative easing programs are buying treasury notes and bonds. On Mar.19 $9^{\text {th }}, 2009$, it bought $\$ 300$ billion of treasury coupons securities and is referred to as "QE1". And on Nov.3 $3^{\text {rd }}, 2010$, it bought another $\$ 600$ billion into the still limping US economy and is referred to as "QE2". Later on, the US Federal Reserve on Sep.14 $4^{\text {th }}, 2012$ announced the third round of quantitative easing (QE3) that entails purchasing \$40 billion each month till the US employment market show recovery sign. The quantitative easing policy may help the US economy in a few ways. Firstly, it can reduce lending cost, as a lower interest rate stimulates investment in the economy. Secondly, the excessive issuance of US dollar will inevitably lead to a depreciation of the currency and push up global commodity prices.

Nevertheless, the Quantitative Easing policy is likely to hurt the Chinese economy in several serious ways. It would devaluate dollar relative to the RMB and makes RMB appreciates. Most importantly, China's inflation and "hot money" are rising, thereby exacerbating asset bubbles. The increasing house prices lead central government concern and published numbers of restricted monetary regulations to stable it. In 2011, central bank raised the deposit-reserve rate six times within six months (Jan $20^{\text {th }}$, Feb $24^{\text {th }}$, Mar $25^{\text {th }}$, Apr. $17^{\text {th }}$, May $18^{\text {th }}$ and June $16^{\text {th }}$ ), up $0.5 \%$ each time. The rate climbed to $21.5 \%$. Moreover, central bank also raised the base lending rate to $6.56 \%$ and base interest rate to $3.50 \%$ in July 2011 . These instruments are showing the policymakers strong willing to tighten monetary policy, reduce the serious inflation and eventually adjust the house price level back to normal. 


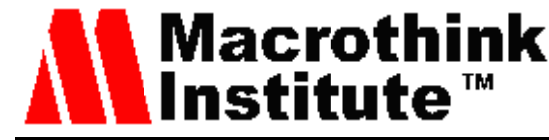

From Figure 1 China overall residential selling prices, in year 2011 the national housing price reached to a peak. Even facing the global financial crisis, the house prices just dipped slightly in 2008 but then showed signs of recovery after that. Because the strong demand from young adult, under the active fiscal policy and loose monetary policy support, it has shown that the real estate prices rose dramatically in year 2009, even higher than that in year 2007. Year 2011 has been considered as the largest house prices increasing year during last 13 years. The house price per square meter climbed up to $6140 \mathrm{RMB}$, comparing with $1933 \mathrm{RMB}$ in year 1998, the house price has increased $218 \%$ in year 2011. Although in year 2012, the central government implemented many new regulations and policies, such as reducing bank loan, prohibit individuals to speculate extra new dwellings. The sales volume seems atrophy, but the residential house price remains strong and reaches to 6639 RMB per square meter in Feb.2013. According to the China Real Estate Index System (CREIS) report "CREIS Hundred Cities Price Index" that was published on June. $3^{\text {rd }}$, 2013, the overall residential housing price of China One Hundred representative cities is 7066 RMB per square meter in May. 2013, the price index signal still shows the increasing trend.

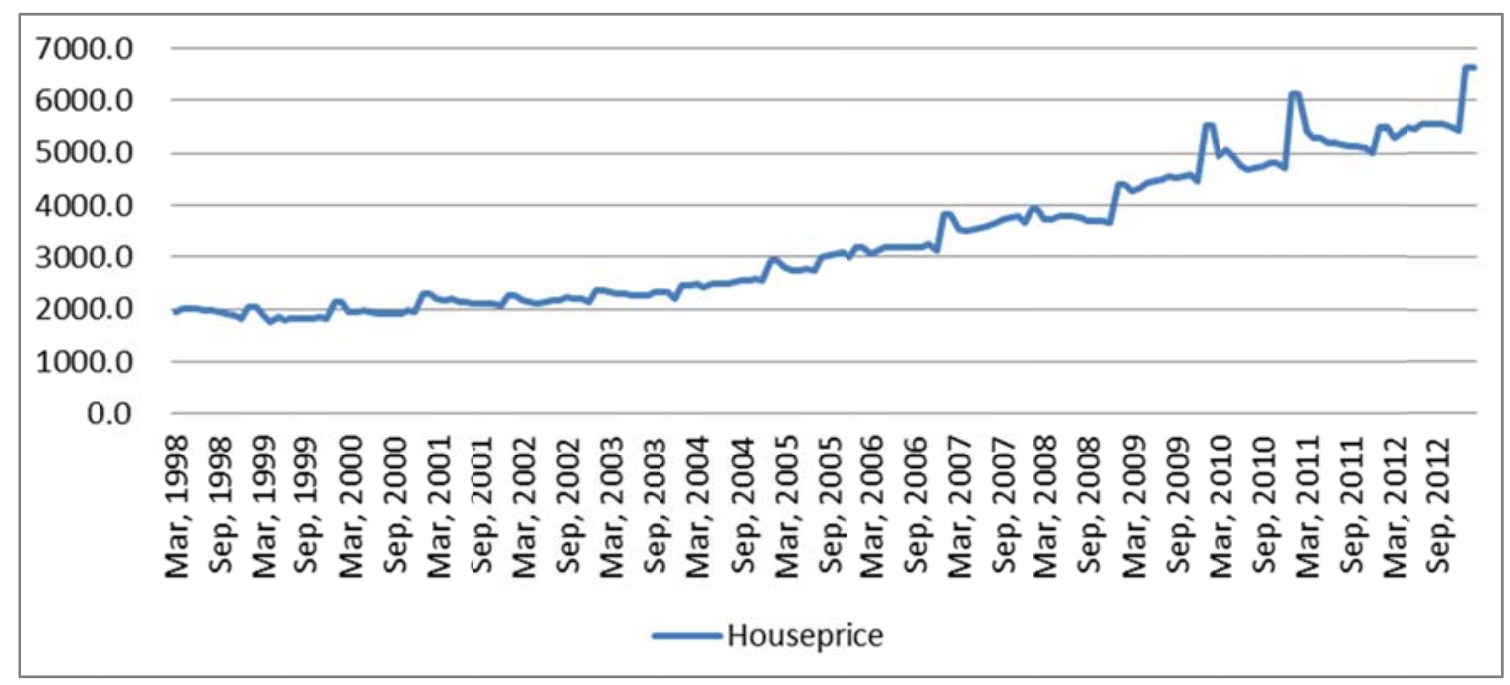

Figure 1. The Trend of Residential Housing Price 1998-2013 (RMB per square meter)

Since China is one of the world's largest countries, real estate industry is the foundation of the national economy and guiding sector, but also pillar industry. In China, the proportion of added value of real estate industry to GDP has increased year by year; the residential housing investment as a share of China's GDP has tripled from 2\% in 2000 to $6 \%$ in 2011. Nowadays, the real estate industry is closely related to the national economy, which is the "barometer" of the national economy. From 2000-2010, China's average house price increased by $225 \%$, house prices have been increasing at high rates especially over recent years $(\mathrm{Wu}$, Gyourko and Deng, 2010).Under this background, we may wonder whether there are bubbles existed in China's residential housing market. We also need to do deep research on the impact of real estate price on every side of the monetary policy framework by using foreign research papers and combing with China's reality. 
Until now, there is no accurate definition of real estate bubble and the "The New Palgrave: A dictionary of Economics" (1987) defined a bubble this way: a sharp rise in price of an asset or a range of assets in a continuous process, with the initial rise generating expectations of further rises and attracting new buyers - generally speculators interested in profits from trading rather than in its use or earning capacity. The rise is then followed by a reversal of expectations and a sharp decline in price, often resulting in severe financial crisis - in short, the bubble bursts. Through the definition we can see that the measure of real estate bubble namely means the departure of prices form fundamental value. (Garber 1990) proposed that the assets traded at their fundamental values by studying of three famous bubble episodes, they are the Dutch tulip mania (1634-1637), the Mississippi Bubble (1719-1720) and the South Sea Bubble (1720). He tried to find the reasonable economic explanations by including the perception of an increased probability of large returns. The perception can be trigged by many things, such as economic news, or unrealistic expectation of future price increases (Case and Shiller, 2003).

\section{Contribution and Benefits of the Study}

This paper examines if rational speculative bubbles occurred in China's residential housing market. We define bubbles as the deviation of real house prices from its market fundamentals. Unlike previous studies, this paper assesses the relationship among house prices and two kinds of variables, i.e. macro-economic variables and monetary variables. By using the $\mathrm{ARCH}$ model, we find that both economic and monetary variables affect changes of residential housing prices. By using direct and indirect tests, we find that there is no significant housing price bubbles exist in national housing market in China. Our finding will help the Chinese government adopt appropriate policy or implement necessary regulations to control the abnormal run-up of house prices.

The remainder of this study is organized as follows: Section 3 is the literature review of previous studies on monetary policy and real estate prices in different countries. Section 4 describes the data used and hypothesis applied in this paper. Section 5 describes financial models to be used in the paper. Section 6 describes the indirect and direct tests bubble methods. At the end of this paper section 7, we make conclusions and put forward some suggestions on the coordinated development of the real estate markets and China economy.

\section{Literature Review on Housing Prices and Fundamental Variables}

There is a large part of extant literature examining the interaction between house prices and national economy. Miller and Peng $(2007,2009)$ provided the relationship between house prices and national wealth effect, and show the result for that there is a positive relationship between them. The national economy growth has a significant effect on the house prices. Costello,G.,Fraser, P.,\& Groenewold, N.(2011) used present value model and found out there is deviations of actual price from its estimated fundamental prices spillover from cities over Australia. 
There are still much of the house price literature reviews market fundamentals derive from demand and supply function, which contains economic variables such as population, unemployment rate, stock of vacant new dwellings, etc. And house prices can be significantly influenced by these factors. Eddie \& Shen (2006) measured the relationship between house prices and market fundamentals in three cities; they are Beijing, Shanghai and HK. They found there are differences between house prices and market fundamentals in HK and Shanghai, and confirmed there are bubbles existed in these two cities in year 2003.

As indicated by the above summary of the fundamental house price literature, the focus has typically been on various measures of "fundamentals". The impact between house prices and monetary policy is another important issue. According the best knowledge of the author, unfortunately, the empirical literature in China on this subject is scarce. And we are the first to examine if there is a speculative bubble in national residential housing market.

In western countries, especially where the real estate market is relatively matured country, both academic and central bank have broadly pay attention to how the asset prices are influenced by monetary policy. (Mishkin 2001, 2007; Iacoviello 2005; Taylor 2007, 2008, 2009) especially studied the relationship between housing prices and monetary policy in USA, and they got the results that monetary policy can significant effect on house prices. Mishkin (2001) studied the relationship among monetary transmission mechanism and stock prices, real estate prices and foreign exchange rates. Except stock market price, the real estate price plays an important role in the monetary transmission mechanism too. The expansionary of monetary policy reduces interest rate, further reduces the cost of financing housing and therefore increases the house price. Mishkin (2007) used the concept of user cost of capital, when there is an interest rate increased the user cost of capital, it will cause a decline in housing demand and prices. As a result, the large run-ups in house price can seriously affect the financial instability, and monetary policy makers should respond to the fluctuation of real estate price. There is empirical evidence on the link from monetary policy to residential prices. Using the structure VAR methodology, Iacoviello (2005) found that the impact of monetary policy on real estate prices during 1974Q1 to 2003Q2. The author identify the monetary policy has significant effect on house price through impulse response model. Giuliodori (2005) provided some quantitative and qualitative evidence of the house price and monetary transmission mechanism across nine European countries. The paper presents the response of house prices to interest rates and the consumption as well. Using a number of VAR models, the author found out the countries with more advantage of mortgage markets and efficient housing system, the relationship between interest rate and house prices will be stronger. Ahearne, Ammer, Doyle, Kole and Martin (2005) studied house prices in 18 advanced economies and also get results that confirm the link from monetary policy to housing prices. Taylor (2007) also provided an early example of a study ascribing a large role to too loose monetary policy in USA, which means too low interest rate, irritates housing activity after the 2001 recession. Taylor (2008, 2009) increased suggesting that loose monetary policy is a primary cause of the bubble in house prices and activity. In the wide selection of empirical papers, the majority researchers conclude the loose monetary policy was a primary cause of the bubble in house prices of western countries. 
Comparing large amount of research papers about western countries' monetary policy effects on house prices, studies on the monetary transmission mechanism in emerging economies, especially China is very limited. Koivu (2010) studied the wealth effect in China, using the VAR model, the loose monetary policy in China actually leads to higher asset prices, especially house prices. Yao, Luo\& Loh (2011) used monthly data from June 2005-September 2010 in China to investigate the long-run relationship between monetary policy and asset prices. Using the VAR model, the empirical results showed that monetary policy has little effect on residential prices, central bank and government should not only use interest rate to maintain the financial stability. They also need to consider many central planning policies when dealing with asset bubbles.

All of the above mentioned papers studied only a part of the factors which effect house prices. Either they look at the relationship between macroeconomic fundamental variables and house prices or they estimate the impact from monetary policy to house prices. They do not investigate the long-run relationship among the national economy, house prices and monetary policy. Also although there are a few studies dealing with monetary policies and asset prices in China, none of them use these key variables to directly and indirectly test and explain if there are rational speculative bubbles in China overall residential housing market.

To sum up, researchers use theoretical and empirical models to show the conflicting results and implication about the monetary policy instrument on house price and relationship between house price bubble and market fundamental. All of them didn't show the clear relationship between the growth economy and monetary policy instruments, which can significantly affect roaring house prices in China. This paper aims to fill in this literature gap. Asset prices especially house prices occupy an important role in national economy. The total fixed asset management has accounted for nearly 50\% of China's Growth Domestic Product. Therefore, investigating the link from macroeconomic variables, monetary policy instrument on house prices, and examining the bubbles and identifying the level of speculative bubbles may provide investors as well as policy makers a better understanding of the volatility and fluctuation of the China residential housing market.

\section{Data and Hypothesis}

Our monthly data source comes from the CEIC Data Ltd, a data provider whose data are from official sources (monthly data details in Appendix A). The research period runs to the Feb.2013 but is restrictive in starting on March 1998 due to the availability of data. The relationship between real estate prices and business cycles has been studied by many researchers. Quigley (1999), Eddie and Shen (2006) and Deng, Ma \&Chiang (2009) used aggregate demand and supply model, the state variables included in their equilibrium models are stock market returns, real GDP, disposable income, unemployment, inflation rate, money supply, and interest rates, etc.. However, the numbers of study about macroeconomic and monetary policy risk influences on the real estate market in China is relatively limited compared to the USA. 
The variables included in this study are hypothesized to act as a set of latent variables which determined return on residential housing prices in China. It is important to know that this set of variables doesn't capture all risk factors, but they indicate the most important variables that affect return on overall residential housing prices in China. In our study, the returns on residential housing prices in China are expected to relate with the following variables: residential housing market investment (Investment), inflation rate (Inflation), lending rate and lagged one period of return on housing prices.

\subsection{Residential Housing Market Investment (Investment)}

There is evidence that increasing of investment will certainly result in housing prices decrease. Since higher investment may lead to weak housing sales, more rising inventories of house for sale, and falling housing prices, these in turn will make building houses less profitable. And so builders and developers are likely to construct fewer new houses and creating an overall reduction in returns on house prices. Therefore, we can assumption the growth in investment has predictive power and has a negative influence to returns on residential housing price in China.

\subsection{Inflation Rate (Inflation)}

Inflation rate influences are very important in China residential housing market. In China, the inflation rate is the relative of the CPI for all urban consumers. This measures the retail prices of several thousand goods and services. The increasing of inflation rate will show the increasing prices trend of all the goods or services purchased by households. Therefore, there is a positive relationship with respect to the change in inflation rate risk on residential housing market.

\subsection{Lending Rate}

This monetary policy indicator is selected because it has significant effect on both the real estate company and the consumers in the market. In general, the nominal interest rates and lending rates in China are controlled by the PBOC (People's Bank of China). Most household buyers are borrowing money through commercial banks. Higher interest rate can reduce the investment activities for both real estate developers and investors. Therefore, lending rate is expected to have negative affect return on residential housing market. So far, several empirical studies have already found out that interest rate helps to explain a significant proportion of the variability in excess returns on property. (Ling and Naranjo, 1997); Liow,K.H.and Huang, Q (2006). The real lending rate is normally calculated from nominal lending rate minus the inflation rate, estimated from CPI. In this paper, we use bank five-year prime lending rate.

Table 1 presents the descriptive statistics of the returns on residential housing prices in China and the selection of the variables for the entire sample period from Mar.1998 to Feb.2013. They include the mean, standard deviation, maximum and minimum, the measures for skewness, kurtosis and Ljung-Box autocorrelation test for all the variables. As can be seen from the Panel A of Table 1, the positive skewness of return on housing price is around 2.212. Excess kurtosis of greater than 3 is found 10.592; it is leptokurtic with greater positive 
kurtosis in returns distributions indicates increased risk. From the preliminary analysis, it indicates the potential for rational speculative bubbles. However, these diagnostic tests are still inconclusive, since the fundamental values can also be associated with these attributes. In next section, we will present the results of more formal bubbles tests. Panel B of Table 1 also reports Ljung-Box statistics tests for the returns on housing prices and all the variables. The autocorrelation denotes Q (6) and Q (12) are statistically significant at the 1\% level. Q (12) tests twelve months of lag operations. The variables show positive autocorrelation, the null hypothesis of no autocorrelation is rejected at lag 6 and lag 12 for all variables.

Table 1. Descriptive Statistics of Return and Variables, 1998-2013

\begin{tabular}{|c|c|c|c|c|c|}
\hline Variables & Period & $\mathbf{N}$ & & Mean & $\begin{array}{l}\text { Standard } \\
\text { Deviation }\end{array}$ \\
\hline \multicolumn{6}{|c|}{ Panel A: Descriptive Statistics } \\
\hline Return on HP & 1998:03-2013:02 & & 179 & 0.0069 & 0.0509 \\
\hline Investment & 1998:03-2013:02 & & 180 & 12.7739 & 1.3858 \\
\hline Inflation & 1998:03-2013:02 & & 180 & 1.8828 & 2.5359 \\
\hline Lending Rate & 1998:03-2013:02 & & 180 & 6.3319 & 0.8332 \\
\hline \multicolumn{6}{|c|}{ Panel B: Autocorrelation of the variables } \\
\hline & $\mathrm{P}(1)$ & $\mathrm{P}(2)$ & & $\mathrm{P}(3)$ & $\mathrm{P}(4)$ \\
\hline Return on HP & -0.112 & -0.289 & & +0.028 & +0.005 \\
\hline Investment & +0.825 & +0.642 & & +0.523 & +0.437 \\
\hline Inflation & +0.967 & +0.924 & & +0.874 & +0.815 \\
\hline Lending Rate & +0.919 & +0.831 & & +0.737 & +0.642 \\
\hline Variables & Min & Max & & Skewness & Kurtosis \\
\hline \multicolumn{6}{|c|}{ Panel A: Descriptive Statistics } \\
\hline Return on HP & -0.123 & +0.262 & & +2.212 & +10.592 \\
\hline Investment & +9.328 & +15.412 & & -0.249 & +2.505 \\
\hline Inflation & -2.200 & +8.700 & & +0.554 & +2.595 \\
\hline Lending Rate & +5.580 & +9.720 & & +1.829 & +7.106 \\
\hline \multicolumn{6}{|c|}{ Panel B: Autocorrelation of the variables } \\
\hline & $\mathrm{P}(5)$ & $\mathrm{P}(6)$ & & $Q(6)$ & $\mathbf{Q}(12)$ \\
\hline Return on HP & -0.065 & +0.009 & & $+18.481 * * *$ & $+136.07 * * *$ \\
\hline Investment & +0.384 & +0.363 & & $+338.90 * * *$ & $+741.12 * * *$ \\
\hline Inflation & +0.748 & +0.674 & & $+783.60 * * *$ & $+974.97 * * *$ \\
\hline Lending Rate & +0.601 & +0.551 & & $+583.41 * * *$ & $+743.58 * * *$ \\
\hline
\end{tabular}

Notes: Return on $\mathrm{HP}=$ monthly returns on housing market; Investment=residential housing market investment; Inflation=monthly inflation rate; lending rate=five year banking lending rate, $\mathrm{Q}(6)$ and $\mathrm{Q}(12)$ are the Ljung-Box(1978) portmanteau test statistics for 6 and 12 autocorrelations. ${ }^{* * *}$ indicates significance at the $1 \%$ level. 


\section{Financial Models: Risk and Return}

\subsection{Arbitrage Pricing Model}

In the section, we first examine the impact of systematic risks on the excess return of the residential housing prices in China. The CAPM provides a framework relating idiosyncratic and systematic market risks with excess returns of assets. An alternative approach to model the relationship between risk and returns of financial assets is to explain the returns of an asset by macroeconomic variables, monetary policy variables or changing business conditions. The approach of modeling the expected return of a financial asset as a linear function of various macro-economic factors was initially suggested by Ross (1976) and is generally known as APT.

Same as CAPM, in APT the sensitivity of the returns to changes in each risk factor is represented by a factor specific $\beta$ coefficient, however, APT allows for $\mathrm{n}$ different factors.

The return of an investment can be determined according to the following equation:

$$
R_{i}=\alpha_{i}+\left(\sum_{j=1}^{n} \beta_{i j} F_{j}\right)+\varepsilon_{i}
$$

Where $R_{i}$ denotes the excess return on the asset, $\alpha_{i}$ denotes some constant term, $\beta_{i j}$ denotes the sensitivity coefficient of asset return to risk factor $F_{j}$.And $\varepsilon_{i}$ denotes the idiosyncratic or error term, that cannot be explained by risk factor.

Since the explanation of the CAPM using only a single market factor maybe limited for real estate returns, we will use the expanding macroeconomic and monetary policy variables in APT to investigate the excess returns on residential housing prices in China. Many oversea theoretical and empirical works (MaCue and Kling, 1994; Ling and Naranjo, 1997; Karolyi and Sanders, 1998; and Liow, K.H., Ibrahim, M.F., and Huang, Q., 2006) had already focused the link between property (or real estate) returns and macroeconomic variables. Chen et al (1986) and Chen (1991) have documented a strong relationship between the US stock returns and real economic variables such as real GDP, industrial production, inflation, and interest rates, etc. Chen (1991) mentioned that it is important to choose the macroeconomic and monetary variables in a way consistent with their forecasts of asset returns. As mentioned earlier, we choose residential housing market investment (Investment), inflation rate (inflation), lending rate and lagged one period of return on housing prices variables.

\subsection{ARCH Model}

A financial model such as $\mathrm{ARCH}$ is able to capture volatility clustering and predict the conditional variance. According to Engle (1982), the first difference of financial time series often exhibit wide volatility, which means the variance of financial time series varies over time. The ARCH model can adequately fit most financial time series data. The model is extended in this paper to include additional explanatory variables in the mean equation. The ARCH (1) model used for estimation is as follows: 


$$
\begin{gathered}
R_{t}=\beta_{0}+\beta_{1} \sum_{i=1}^{n} R_{t-i}+\beta_{2} \text { DInvest }_{t}+\beta_{3} \text { DINF }_{t}+\beta_{4} \text { LR }_{t}+\varepsilon_{t} \\
\varepsilon_{t}=\alpha_{0}+\alpha_{1} \varepsilon_{t-1}^{2}
\end{gathered}
$$

In this model, $R_{t}$ is the excess return on the housing market, $R_{t-i}$ is the autoregressive lag of excess returns in the mean equation, $\varepsilon_{t}$ is the residual term, and the parameters are $\beta_{0}, \beta_{1}, \beta_{2}$, $\beta_{3}, \beta_{4}, \alpha_{0}, \alpha_{1}$. In the mean equation, the optimal lag structure is determined to be $1(\mathrm{n}=1)$ for the excess returns in order to eliminate the autocorrelation for the residual term. To ensure the variance $\varepsilon_{t}$ is well defined, the parameters $\alpha_{0}$ and $\alpha_{1}$ must be positive.

\subsection{Interpretation of the Results}

According to the output result, we can write down the ARCH (1) model estimate results as follow. Results show several findings and implications. The expected excess returns on housing market in China are positively correlated with lagged one period of return on housing prices variables, change in inflation rate, and negatively correlated with the lending rate. The $\mathrm{ARCH}$ parameter $\alpha_{1}$ is significant positive at 1.039 . With adjusted $\mathrm{R}$ square equals 0.996571, we also test the significance of any individual $\beta$ coefficient by the test and the results show that all the coefficients are significant. The result shows that ARCH (1) model is quite capable of explaining variations in excess returns on China residential housing market.

$$
\begin{gathered}
R_{t}=1.51+0.55 R_{t-1}-0.05 \text { DInvest }_{t}+0.58 \text { DINF }_{t}-0.42 L R_{t}+\varepsilon_{t} \\
\begin{array}{c}
(0.06)(0.02) \\
\varepsilon_{t}
\end{array}=0.004+1.039 \varepsilon_{t-1}^{2}
\end{gathered}
$$

\section{Direct and Indirect Bubbles Tests}

\subsection{Unit Root Test Analysis and Results}

Diba and Grossman (1988) indicated that a rational bubble must have always existed from the first day of trading. Using Dickey-Fuller tests, Diba and Grossman find that both dividends and stock prices are stationary in difference. The results show the non-stationary in the level is caused by market fundamentals, not by speculative bubbles. We use Augmented Dikey Fuller (ADF) (1979) and Phillips Perron (PP) (1987) unit root tests to measure the stationary of the price of residential housing and the fundamental variables. Then we can use cointegration analysis to test for rational speculative bubbles. According to Diba and 
Grossman (1988), if there is long-term relationship existed between prices and fundamentals; we will have evidence against the presence of a bubble.

In order to check the stationary of house prices and fundamental variables, we apply the ADF and PP unit root tests in this paper. The tests in here consist of estimating the following regression. For ADF test:

$$
\Delta Y_{t}=\beta_{1}+\beta_{2} t+\delta Y_{t-1}+\sum_{i=1}^{m} \alpha_{i} \Delta Y_{t-i}+\varepsilon_{t}
$$

Where $\Delta Y_{t-1}=\left(Y_{t-1}-Y_{t-1}\right)$.If $\delta=0$, then the $\mathrm{Y}$ series has a unit root. Which means the series is non-stationary.

For PP test:

$$
Y_{t}=\beta_{1}+\beta_{2} Y_{t-1}+\varepsilon_{t}
$$

If $\beta_{2}=1$, then the $\mathrm{Y}$ series has a unit root.

In table 2, panel A and B report the house price and macroeconomic and monetary variables unit root test results for the period during Mar.1998-Feb.2013. The report shows the intercept and trend or without it. Both results show that all the variables are non-stationary at the levels of time series, but they are stationary after the first difference I (1). The null hypothesis of a unit root cannot be rejected when the variables are measured at the level, but is rejected at their first differences. Based on the unit root tests, table 2 shows no evidence of residential pricing bubbles during Mar.1998-Feb.2013.Because it is clear to see that all variables are stationary at their first difference rather than level, it is possible to establish a long-run relationship between price and fundamentals, it is evidence against the presence of a bubble.

\begin{tabular}{|c|c|c|c|c|}
\hline Variables & ADF & & PP & \\
\hline & No Trend & Trend & No Trend & Trend \\
\hline \multicolumn{5}{|c|}{ Panel A: House Price and Variables at level } \\
\hline LnHP & 0.60 & -3.09 & 0.55 & $-3.34 * *$ \\
\hline LnInvestment & -1.32 & -1.93 & -2.97 & -2.89 \\
\hline Inflation & -2.15 & -1.03 & -2.23 & -1.25 \\
\hline Lending Rate & -2.23 & -1.67 & -2.23 & -1.66 \\
\hline \multicolumn{5}{|c|}{ Panel B: Change in House Price and Variables } \\
\hline DLnHP & $-3.14 * *$ & $-3.31 * *$ & $-52.03 * * *$ & $-41.12 * * *$ \\
\hline DInvestment & $-3.05 * *$ & $-3.27 * *$ & $-721.00 * * *$ & $-528.60 * * *$ \\
\hline DInflation & $-5.70 * * *$ & $-5.70 * * *$ & $-16.23 * * *$ & $-16.18 * * *$ \\
\hline DLending Rate & $-12.34 * * *$ & $-12.35 * * *$ & $-12.34 * * *$ & $-12.35 * * *$ \\
\hline
\end{tabular}

Table 2. ADF and PP Unit Root Tests of Variables, Mar.1998-Feb.2013 
Notes:

Three macroeconomic and monetary policy variables used as a proxy for fundamental factors are gross domestic product, inflation rate, and real lending rates.

Corresponding critical values for model with only intercept for ADF and PP unit root tests are $-3.47,-2.88$, and -2.57 for 1,5 , and 10 percent significant level, respectively.

Corresponding critical values for model with intercept and trend for ADF and PP unit root tests are $-4.02,-3.44$ and -3.14 for 1,5 , and 10 percent significant level, respectively.

$* * *, * *$, and $*$ indicate significant at the $1 \%, 5 \%$, and $10 \%$ levels.

\subsection{Co-integration Test Analysis and Results}

We use the Johansen and Juselius (1990) test to estimate the number of co-integration or long-run relationship between the residential house prices and the fundamental variables. If they are co-integrated, there is no bubble exists (Diba and Grossman, 1988). The test is based on the following vector autoregression (VAR) model:

$$
Y_{t}=A_{1} Y_{t-1}+A_{2} Y_{t-2}+\ldots+A_{p} Y_{t-p}+\varepsilon_{t}, t=1,2, \ldots, \mathrm{n}
$$

Where $Y_{t}$ is a vector of non-stationary variables, $Y_{t}=(\mathrm{LnHP}$, LnInvestment, Inflation,

Lending rate). $A_{p}$ is $\mathrm{K} * \mathrm{~K}$ matrix contains information about the relationships among these variables.

Johansen and Juselius (1990) provide maximum eigenvalue test and trace test to examine the number of cointegrating vectors among these variables. The null hypothesis of maximum eigenvalue test is that there are at most $r$ cointegrating vectors. The null hypothesis of trace test is that the number of cointegrating vectors is less than or equal to $r$.

When applying cointegrating test, all the variables in the VAR model should be non-stationary. From the table 2 of unit root test results, we can see that all variables are having unit roots at their levels. Table 3 reports the JJ co-integration rank test results. The $\lambda_{\text {trace }}$ and $\lambda_{\max }$ based on 12 lags for the entire period. Evidence shows that there are more than one cointegrating relationship for residential housing prices and macroeconomic and monetary variables. Since both $\lambda_{\text {trace }}$ and $\lambda_{\max }$ statistics tests reject the null hypothesis of $r \leq 1$ according to $r=2$ at the $5 \%$ and $1 \%$ significance level. Therefore, the null hypothesis of no integration can be rejected by both the trace and max-Eigenvalue statistics at the $5 \%$ and $1 \%$ significant level. The results show the residential housing prices and fundamental variables are co-integrated over the entire period. That implies there is long run relationship among house prices and fundamental variables. Thus, we can conclude that the presence of speculative bubbles can be rejected. 
Table 3. Johansen Test Results for Linear Co-Integration among Variables

\begin{tabular}{|c|c|c|c|c|c|c|c|}
\hline \multirow[t]{2}{*}{$\begin{array}{l}\text { Study Period } \\
1998-2013\end{array}$} & \multirow[t]{2}{*}{$H_{0}$} & \multirow[t]{2}{*}{$\begin{array}{l}\text { Trace } \\
\text { Statistics }\end{array}$} & \multicolumn{2}{|c|}{$\begin{array}{l}\text { Trace Statistics } \\
\text { Critical Value }\end{array}$} & \multirow[t]{2}{*}{$\begin{array}{l}\text { Max } \\
\text { Eigenvalue }\end{array}$} & \multicolumn{2}{|c|}{$\begin{array}{l}\text { Max Statistics } \\
\text { Critical Value }\end{array}$} \\
\hline & & & CV5\% & CV1\% & & CV5\% & CV1\% \\
\hline & $r=0$ & 130.91 & $63.87^{*}$ & $71.48 * *$ & 63.55 & $32.12^{*}$ & $37.49 * *$ \\
\hline & $r \leq 1$ & 67.36 & $42.91 *$ & $49.36^{* *}$ & 40.05 & $25.82^{*}$ & $30.83^{* *}$ \\
\hline & $r \leq 2$ & 27.30 & $25.87^{*}$ & 31.15 & 17.58 & 19.38 & 23.98 \\
\hline
\end{tabular}

Notes:

Twelve lag were used in all cointegration vectors based on Akaike's Information Criteria. $H_{0}$ is the null hypothesis that there exists at most $r$ cointegration vectors in the system.

The cointegration tests are estimated under the assumption of trend in data and an intercept and trend in the cointegrating equation.

$\mathrm{CV}(5 \%)$ and $\mathrm{CV}(1 \%)$ are the critical values of the trace statistics and maximum Eigenvalue statistics for cointegration tests.

**indicates significance at the $1 \%$ level and * indicates significance at the $5 \%$ level.

\subsection{Duration Dependence Test Analysis and Results}

Duration dependence test is a new testable implication for bubbles, which is developed by McQueen and Thorley (1994) the duration dependence test suggests that the probability that a run of positive abnormal returns will end should decline with the length of the run.(negative hazard function). This test is more flexible and has no requirement of the identification of specific fundamental factors and also doesn't require that the time series have to be normally distributed. (Abdul-Haque, Wang and Oyand, 2008; Jirasakuldech, Emekter and Rao, 2007).

Duration dependence test has been widely applied and supported to investigate the presence of rational speculative bubbles in various academic fields, such as real estate market (Jirasakuldech, Campbell and Knight, 2006), and equity market (McQueen and Thorley, 1994). In our research paper, the test performed on Log-logistic model. And the runs are created using nominal housing prices returns.

To apply the duration dependence tests, this study follows the method as adopted by Blanchard and Watson (1982), Evan (1986) and McQueen and Thorley (1994), in which returns are first required to transform into series of run lengths of two data sets, which are positive and negative observed returns for monthly data. A run is defined as a sequence of returns of the same signs.

The sample hazard rates of runs of positive and negative returns are estimated based on the formula.

$$
h_{i}=N_{i} /\left(M_{i}+N_{i}\right)
$$




\section{Al Macrothink

Where $\mathrm{Ni}$ is the count of runs of length $\mathrm{i}$ and $\mathrm{Mi}$ is the count of runs with a length greater than i. Under the null hypothesis of no bubble or no duration dependence, we should observe a constant hazard rate, which implies that the abnormal returns exhibit a random walk in China residential housing market. On the other hand, a decreasing hazard rate suggests the presence of rational speculative bubbles or duration dependence.

A discrete hazard model for duration is constructed for this study following McQueen and Thorley (1994) method, and the log-likelihood function for a sequence of $\mathrm{N}$ runs is expressed as follows:

$$
L\left(\theta / S_{T}\right)=\sum_{i=1}^{N}\left[N_{i} \operatorname{Lnh} h_{i}+M_{i} \operatorname{Ln}\left(1-h_{i}\right)\right]
$$

To perform a test of duration dependence, a function form must be chosen from the hazard function for $h$. This study employs duration dependence test using the Log- logistic model for the detection of rational speculative bubbles. The model will be used in order to ensure that the results are not sensitive to the underlying assumptions of a particular test and that they are not biased. The sample hazard rate for each length $i$, can be estimated from maximizing the $\log$ likelihood function of the hazard function.

The Log-logistic function is defined as:

$$
h_{i}=1 / 1+e^{-(\alpha+\beta L n i)}
$$

Where $\beta$ is the estimated coefficient of run length, this function transforms the unbounded range of $\alpha+\beta \operatorname{Ln}(i)$ into a $(0,1)$ space of $h$, the conditional probability of ending a run. The duration dependence test for logistic hazard function is performed by substituting Equation (6) into (5) and maximizing the log likelihood function with respect to $\alpha$ and $\beta$. Generally, an estimate of $\beta$ that is negative and significantly different than zero for positive runs, in conjunction with an insignificant estimate of $\beta$ for negative runs, is considered evidence of speculative bubbles. (McQueen and Thorley, 1994)

Table 4 reports the duration dependence test with the log logistic model for runs of monthly abnormal returns for the full sample period (Mar.1998-Feb.2013). The positive and negative run counts are listed at each horizon. 
Table 4. Duration Dependence Test Results for Monthly Returns

\begin{tabular}{|c|c|c|c|c|}
\hline Run Length & $\begin{array}{l}\text { Positive Runs } \\
\text { Actual Run } \\
\text { Counts } \\
\text { Total=45 }\end{array}$ & $\begin{array}{l}\text { Sample } \\
\text { Hazard } \\
\text { Rates }\end{array}$ & $\begin{array}{l}\text { Negative Run } \\
\text { Actual Run } \\
\text { Counts } \\
\text { Total=43 }\end{array}$ & $\begin{array}{l}\text { Sample } \\
\text { Hazard } \\
\text { Rates }\end{array}$ \\
\hline 1 & 14 & 0.7045 & 22 & 0.5116 \\
\hline 2 & 22 & 0.3077 & 12 & 0.5714 \\
\hline 3 & 3 & 0.5556 & 4 & 0.4444 \\
\hline 4 & 4 & 0.2500 & 2 & 0.4000 \\
\hline 5 & 1 & 0.6667 & 2 & 0.6667 \\
\hline 6 & 0 & 0.0000 & 0 & 0.0000 \\
\hline 7 & 1 & 0.0000 & 0 & 0.0000 \\
\hline 8 & & & 0 & 0.0000 \\
\hline 9 & & & 0 & 0.0000 \\
\hline 10 & & & 1 & 1.0000 \\
\hline \multicolumn{5}{|l|}{ Log-Logistic } \\
\hline \multicolumn{5}{|l|}{ Test } \\
\hline$\alpha$ & 0.410 & & -0.05 & \\
\hline $\boldsymbol{\beta}$ & -0.448 & & -0.04 & \\
\hline LRT of & -0.467 & & -0.06 & \\
\hline $\begin{array}{l}\text { H0: } \beta=0 \\
\text { (p-value) }\end{array}$ & $(0.64)$ & & $(0.95)$ & \\
\hline
\end{tabular}

Notes:

1. A run of length $i$ is a sequence of $i$ returns of the same sign.

2. Positive and negative returns are defined relative to the housing returns term

3. The sample hazard rate represents the conditional probability that a run ends at $i$, given that it lasts until i,

4. The log-logistic function is. $\beta$ is the hazard rate which is estimated using the logistics regression where independent variable is the log of current length of the run and dependent variable is 1 if the run ends and 0 if it does not end in the next period.

5. The LRT (likelihood ratio test) of the null hypothesis, H1: $\beta=0$, of no duration dependence

(Constant hazard rate) follows the $\chi^{2}(1)$ distribution.

6. P-value is the marginal significance level, which is the probability of obtaining that value of the LRT or higher under the null hypothesis.

The sample hazard rate estimates the probability that a run ends at $i$, which means it lasts until i. For example, the hazard rate associated with a positive run length of 5 month is 0.5 . This means that if a positive run persists for five consecutive months, there is $50 \%$ 
probability that the bubble will burst in the next month.

The maximum likelihood estimates of the log-logistic function parameters $\alpha$ and $\beta$ are reported as well. As shown in table 4 , the runs of positive returns exhibit negative $\beta$ coefficient $(\beta=-0.448)$, the confidence interval ( $p$-value) are based on LRT, which is the probability of obtaining the value of LRT or higher under the null hypothesis of no bubble $(\beta=0)$. The result of the likelihood ratio test (LRT) of $\beta$ is insignificant (P value; 0.64). As a result, during the full sample period with the monthly data, no bubble hypothesis will not be rejected. The negative returns exhibit negative $\beta$ coefficient $(\beta=-0.04)$, but the results is not significant since the $\mathrm{P}$ value is 0.95 , which is also inconsistent with the rational bubbles.

In summary, during the full sample period, the results for both positive and negative runs do not support the evidence of the existence of rational speculative bubbles in China residential housing market with the log-logistic models with monthly housing prices returns.

\section{Summary and Conclusions}

This paper aims to increase our understanding of the relationship among national economy, residential housing prices and monetary policy in China. In particular, we have tried to answer the question whether the fundamental variables influence housing prices. The detection of rational speculative bubbles in the housing market is also explored.

Some limitation of the research should be noticed before we highlight our key findings. First, there are some limitations for data collections. The national data can only be given from year 1998, since there was no real private market neither in housing unit or land market till 1998. Therefore, we can only compare current conditions with little more than a decade of data. In fact, the data about national average residential selling prices are all collected from a booming period. Second, the macroeconomic and monetary policy variables used in the model specified in this study are partial macroeconomic and monetary policy system, the research didn't permit a full investigation of other indirect influences on the house prices; Third, the regional areas bubbles, such as Beijing, Shanghai, Guangzhou individual cities bubbles should be examined as well. Finally, the assumption and specification are necessary for empirical purposes and there has space for future research to address these shortcomings.

Our finding indicates there is a long-run relationship between overall residential housing prices and its important fundamentals. However, the real lending rate has a relative weakly effect on the house prices. This can be understood that China is facing very high inflation in the history; comparing with the low lending and interest rates, the higher return from investing in real estate market attracts Chinese investors tend to take excessive risk and expect the housing prices will increase more. This kind of hedging investment behavior can be explained by various China's unique social and culture factors. China is facing rapid urbanizations, booming national economy, marrying attitude toward household ownership, and lack of investment channel, all these factors together with immature real estate market competition make the key factors responsible for increasing of China residential housing prices. 
From the results found in this paper and plenty of evidence both shown in the econometric analysis results and data factors, China overall residential housing market is facing continuing increasing of house prices, but there is still not occur speculative rational bubbles. The political development in China has a significant impact on market volatility and returns, the unexpected returns jump or drop in the housing market are associated with the political news. The results of this study provide several implications to policymakers on the efficiency of the China residential housing market so the policymakers would provide guidance to the investors to act rationally by adjusting the housing prices in the future.

In order to control the abnormal increasing of residential housing prices, the best policy framework to achieve price and financial stability is to maintain flexible inflation. Thus, this target induces policy makers to adjust interest rate to offset incipient inflationary or deflationary pressure. To avoid the bubbles occurring, the policy makers can consider raising the interest rate as housing prices raise and reducing the interest rate when housing prices fall. In addition, enhancing the transparency of the housing market would make the information easily accessible to investors that are able to reduce information asymmetry to prevent bubbles. Finally, the development of financial infrastructure such as the property tax payment systems and the constructing derivative products which can make investors hedge their risk will eventually control the abnormal increasing of housing prices.

\section{References}

Abdul-Haque, Wang, S., \& Oyang, H. (2008). Rational speculative bubbles in Chinese stock market. International Journal of Applied Economics, 5(1), 85-100.

Ahearne, A. G., Ammer, J., Doyle, B. D., Kole, L. S., \& Martin, R. F. H. (2005). House Prices and Monetary Policy: A Cross-Country Study. Board of Governors of the Federal Reserve System. International Finance Discussion Papers, No. 841.

Blanchard OJ, \& Watson MW (1982). Bubbles, rational expectations, and financial markets. In:Wachtel P (ed) Crisis in the economic and financial system. Lexinton Books, Lexinton,Massachusetts

Case, Karl E., \& Robert J. Shiller. (2003). Is There a Bubble in the Housing Market? Brookings Papers on Economic Activity (Brookings Institution), 2, 299-342.

Chen, N.F. (1991). Financial investment opportunities and macroeconomy. Journal of Finance, 46, 529-54.

Chen, N.F., Roll, R., \& Ross, S. (1986). Economic forces and the stock markets. Journal of Business, 59, 383-403.

Costello,G., Fraser, P., \& Groenewold, N. (2011). House Prices, non-fundamental components and interstate spillovers: The Australian Experience. Journal of Banking \& Finance, 35, 653-669. 
Deng, C.R., Ma, Y.K., \& Chiang, Y.M. (2009). The Dynamic Behavior of Chinese Housing Prices. International Real Estate Review, 12(2), 121-134.

Diba BT, \& Grossman HL (1988). Explosive bubbles in stock prices. American Economic Review, 78, 520-530.

Dickey D, \& Fuller W (1979). Distribution of the estimators for autoregressive time series with a unit root. J Am Stat Assoc, 74(366), 427-431.

Eddie C. M. Hui \& Shen Yue. (2006). Housing price bubbles in Hong Kong, Beijing and Shanghai: A Comparative Study. Journal of Real Estate Finance and Economics, 33, 299-327. http://dx.doi.org/ 10.1007/s11146-006-0335-2

Engle,R. (1982). Autoregressive conditional heteroscedasticity with estimates of the variance of United Kingdom inflation. Econometrica, 50(1), 987-1007

Evans, G.W. (1986). A test for speculative bubbles in the sterling dollar exchange rate: 19811984. American Economic Review, 76, 621-636

Garber, P.M. (1990). Famous first bubbles. Journal of Economic Perspective, 4, 35-54.

Giuliodori, M. (2005). The Role of House Prices In the Monetary Transmission Mechanism across European Countries. Scottish Journal of Political Economy, 52(4), 519-543.

Iacoviello, M. (2005). House Prices, Borrowing Constraints, and Monetary Policy in the Business Cycle. American Economic Review, 95(3), 739-764.

Jirasakuldech, B., Campbell, R.D., \& Knight, J. R. (2006). Are there rational speculative bubbles in REITs? Journal of Real Estate Finance and Economics, 32, 105-127. http://dx.doi.org/ 10.1007/s11146-006-6010-9

Jirasakuldech, B., Emekter, R., \& Rao, R. (2007). Do Thai stock prices deviate from fundamental values? Pacific-Basin Finance Journal, 16, 298-315. http://dx.doi.org/10.1016/j.pacfin.2007.01.001

Johansen, J., \& Juselius, K. (1990). Maximum likelihood estimation and inferences on cointegration-with application to the demand for money. Oxf Bull Econ Stat, 52(2), 169210.

Karolyi, G.A., \& Sanders, A.B. (1998). The variation of economic risk premiums in real estate returns. Journal of Real Estate Finance and Economics, 17(3), 245-62. http://dx.doi.org/10.1007/s11146-006-6010-9

Koivu, T. (2010). Monetary Policy, Asset Prices and Consumption in China, European Central Bank, Working Paper Series, No. 1240, ECB.

Ling, D.C., \& Naranjo, A. (1997). Economic risk factors and commercial real estate returns. Journal of Real Estate Finance and Economics, 14, 283-301. 
Liow, K.H., \& Huang, Q. (2006). Interest rate risk and time-varying excess returns for Asian property stocks. Journal of Property Investment and Finance, 24(3), 188-210. http://dx.doi.org/ 10.1108/14635780610659919

Liow, K.H., Ibrahim, M.F., \& Huang, Q. (2006). Macroeconomic risk influences on the property stock market. Journal of Property Investment and Finance, 24(4), 295-323. http://dx.doi.org/ 10.1108/14635780610674507

McCue, T.E., \& Kling, J.L. (1994). Real estate returns and the macroeconomy: empirical evidence. Journal of the American Real Estate and Urban Economic Association, 15(3), 234-55.

McQueen, G., \& Thorley, S. (1994). Bubbles, stock returns, and duration dependence. Journal of financial and quantitative analysis, 29(3), 379-401

Miller, Norman, \& Liang Peng. (2007). House Prices and Economic Growth, University of Colorado Working Paper.

Miller, Norman, Liang Peng, \& Michael Sklarz. (2009). House Prices and Economic Growth. Journal of Real Estate Finance and Economics, 42(4), 522-541. http://dx.doi.org/10.1007/s11146-009-9197-8

Mishkin, Frederic S. (2001). The Transmission Mechanism and The Role of Asset Prices in Monetary Policy. NBER Working Paper Series 8617. Cambridge, Mass: National Bureau of Economic Research, December

Mishkin, Frederic S. (2007). Housing and the Monetary Transmission Mechanism. NBER Working Paper Series 13518. Cambridge, Mass: National Bureau of Economic Research, October.

Phillips P., \& Perron P. (1987). Testing for a unit root in time series regression. Biometrica $75,335-346$.

Quigley, J.M. (1999). Real estate prices and economic cycles. International Real Estate Review, 2(1), 1-20.

Ross, S.E. (1976). The arbitrage theory of capital asset pricing. Journal of Economic Theory, 13, 341-60.

Taylor, John B. (2007). "Housing and Monetary Policy," NBER Working Paper Series 13682. Cambridge, Mass.: National Bureau of Economic Research, December, www.nber.org/papers/w13682.pdf

Taylor, John B. (2009). "The Financial Crisis and the Policy Responses: An Empirical Analysis of What Went Wrong," NBER Working Paper Series 14631. Cambridge, Mass.: National Bureau of Economic Research, January. www.nber.org/papers/w14631

Taylor, John. (2008). “The Financial Crisis and the Policy Responses: An Empirical Analysis of What Went Wrong," speech delivered at a Festschrift in Honor of David Dodge's 
Contributions on Canadian Public Policy at the Bank of Canada, November, www.bankofcanada.ca/en/conference/2008/taylor.pdf

Wu, Jing., Gyourko, Joseph., \& Deng, Yongheng. (2010). Evaluating conditions in major Chinese housing markets NBER Working Paper Series 16189. Cambridge, Mass: National Bureau of Economic Research, July.

Yao, Shujie., Luo, Dan., \& Loh, Lixia. (2011). On China's monetary policy and asset prices Discussion Paper 71. The University of Nottingham, China Policy Institute, March.

Appendix A. Data Source and Definitions

\begin{tabular}{|c|c|c|c|}
\hline Variables & Definition & Sample Frequency & Source \\
\hline $\mathrm{HP}$ & $\begin{array}{l}\text { National Residential } \\
\text { housing prices }\end{array}$ & $\begin{array}{l}\text { Monthly data } \\
1998-2013\end{array}$ & CEIC \\
\hline Investment & $\begin{array}{l}\text { Residential Housing } \\
\text { Market Investment }\end{array}$ & $\begin{array}{l}\text { Monthly data } \\
1998-2013\end{array}$ & CEIC \\
\hline Inflation & Inflation rate & $\begin{array}{l}\text { Monthly data } \\
1998-2013\end{array}$ & CEIC \\
\hline Lending Rate & $\begin{array}{l}\text { Five year long term } \\
\text { mortgage rate }\end{array}$ & $\begin{array}{l}\text { Monthly data } \\
1998-2013\end{array}$ & CEIC \\
\hline
\end{tabular}

\section{Copyright Disclaimer}

Copyright reserved by the author(s).

This article is an open-access article distributed under the terms and conditions of the Creative Commons Attribution license (http://creativecommons.org/licenses/by/3.0/). 